\title{
Vermicomposting of domestic waste by using two epigeic earthworms (Perionyx excavatus and Perionyx sansibaricus)
}

\author{
${ }^{1}$ *S. Suthar; ${ }^{2}$ S. Singh \\ ${ }^{1}$ Department of Zoology, J. N. Vyas University, Jodhpur-342 001, India \\ ${ }^{2}$ Department of Chemistry, N.M. (PG) College, Hanumangarh Town-335 513, India \\ Received 9 January 2007; revised 5 May 2007; accepted 20 October 2007; $\quad$ available online 26 December 2007
}

\begin{abstract}
The composting potential of two epigeic earthworms (P. excavatus and P. sansibaricus) was studied in 2002 to breakdown the domestic waste under laboratory conditions. The experimental container with $P$. sansibaricus showed maximum mineralization and decomposition rate than that of $P$. excavatus. Except for exchangeable $\mathrm{K}$ (it was higher $(P=0.004)$ in a container with $P$. excavatus), the domestic waste processed by $P$. sansibaricus showed about $6 \%$ more total nitrogen $(P=0.002)$ and about $7 \%$ more available $P(P=0.269)$ at the end than by $P$. excavatus. As compared with the initial level organic $\mathrm{C}$ content as well as $\mathrm{C}: \mathrm{N}$ ratio showed a considerable reduction that was noted higher in substrate with $P$. sansibaricus than those by $P$. excavatus (organic C, $t$-test: $P=0.870$; C:N ratio, $t$-test: $P=0.002$ ). The growth (biomass increase) and reproduction parameters such as mean individual live weight, maximum individual growth rate (mg wt./worm/day), number of cocoons and reproduction rate (cocoon/worm/day) were higher in bedding with $P$. sansibaricus. The maximum earthworm mortality was in vermibed having $P$. sansibaricus ( $\sim 50 \%$ higher than by $P$. excavatus) (t-test: $P=0.423)$, since both species did not show a drastic difference in waste mineralization rate, but comparatively, P. excavatus exhibited better growth and reproduction performance, which further support the suitability of the species for large scale vermiculture operations.
\end{abstract}

Key words: Earthworm, vermicomposting, domestic waste, cow dung, cocoon, epigeic earthworms

\section{INTRODUCTION}

Vermicomposting is an eco-biotechnological process that transforms energy-rich and complex organic substances into stabilized humus-like product vermicompost. Benitez, et al., (1999) concluded that in vermicomposting process, inoculated earthworm maintains aerobic condition in the organic wastes, converts a portion of the organic material into worm biomass and respiration products and expels the remaining partially stabilized product, since the potential of some epigeic earthworm to recycle organic waste materials into value-added products is well documented (Kale, et al., 1982; Elvira, et al., 1998; Manna, et al., 2003; Garg and Kaushik, 2005; Garg, et al., 2006; Suthar, 2006 and 2007a). The end product, i.e. vermicompost is considered as an excellent product, since it is homogenous, has desirable aesthetics, has reduced levels of contaminants and tends to hold more nutrients over a longer period

\footnotetext{
*Corresponding Author Email:

sutharss_soilbiology@yahoo.co.in

Tel.: +91 154247 0452; Fax: +91 1542475960
}

without impacting the environment. Rapid urbanization resulted in an ever-increasing accumulation of urban solid waste. In India, domestic waste is mostly of organic nature and contributes 70$80 \%$ to the total solid urban waste. However, it can be used as a potential resource for transformation from expensive disposal problem to stabilized vermicompost production for sustainable land restoration practices. Some epigeic earthworms: Lumbricus terrestris, Eisenia fetida, E. andrei, Eudrilus eugeniae and Perionyx excavatus have been appeared as key sources to combat the problems of organic waste disposal on a low-input basis (Kale, et al., 1982; Butt, 1993; Elvira, et al., 1998; Dominguez, et al., 2001; Garg and Kaushik, 2005; Suthar, 2006). Recently, Suthar (2007a and c) demonstrated the potential of a new species, i.e. P. sansibaricus, for waste decomposition operations. However, $P$. excavatus and $P$. sansibaricus are considered as endemic to Indian soils and are commonly distributed in many natural soil ecosystems. However, the waste 
decomposition efficiency of $P$. excavatus is well documented in literature (Kale, et al., 1982; Edwards, et al., 1998; Suthar, 2006; Suthar, 2007b). But little is known about the composting use of $P$. sansibaricus. Therefore, to establish the use of this species for vermicomposting operations, much work is still required, since both species of genus Perionyx have distinct morphological characteristics and also possibly waste degradation patterns though they may later enquire much experimental confirmation. However, comparative studies on composting efficiencies on these species still need richer literature. The comparison of the composting efficiency can be performed by using a common substrate for both species. In most of the previous studies on $P$. excavatus, cattle dung and/or plant-derived wastes were used as substrate material in vermicomposting experiments (Kale, et al., 1982; Edwards, et al., 1998; Manna, et al., 2003; Suthar, 2006; Suthar, 2007 b). In this study, efforts have been made to compare the composting potential of $P$. excavatus and $P$. sansibaricus by using a common substrate or culture material such as household waste that had not been explored extensively in previous studies.

\section{MATERIALS AND METHODS}

The domestic waste (household waste) was collected locally from randomly selected residential houses of municipal territory of the study area. The cow dung, having the characteristics of $\mathrm{pH} 7.83$, organic C $298.23 \mathrm{~g} / \mathrm{kg}$, total N $5.72 \mathrm{~g} / \mathrm{kg}$, available P $2.35 \mathrm{~g} / \mathrm{kg}$, exchangeable K $5.68 \mathrm{~g} / \mathrm{kg}$ and C:N ratio 52.19 , was procured from a local cowshed. The waste was collected in large-sized plastic circular pot containers and was brought to laboratory. The nonrecyclable items such as plastic, rubber, polythene bags, wood, cardboard and glass were separated through hand sorting from collected domestic waste. $P$. excavatus used in this study was obtained from Prof. Radha D. Kale, University of Agriculture Science, Bangalore. Another used species, i.e. P. sansibaricus (Perrier), was obtained from stock culture maintained in laboratory, originally collected from a local sewage soil. The waste material used in this experiment was dried at $60^{\circ} \mathrm{C}$ and chopped into small pieces. The dried waste was mixed with amendment material, i.e. cow dung in 2:1 ratio (dry weight proportion in plastic containers). The mixture of domestic waste and cow dung in container served as bedding as well as feed for worms. Plastic circular containers $(28 \mathrm{~cm}$ diameter and $30 \mathrm{~cm}$ in depth) with pierced lids for aeration were used for vermicomposting experiments. Experimental beddings were kept in triplicate for each tested earthworm species and another triplicate for each earthworm without earthworms served as the experimental control. All beddings were kept for 2 weeks prior to the experimentation for thermal stabilization, initiation of microbial degradation and softening of waste. Twenty-four-week old clitellated individuals of each species: $P$. excavatus and $P$. sansibaricus (having individual live weight » 252 $254 \mathrm{mg}$ ) were collected from the stock culture and released into different containers containing $750 \mathrm{~g}$ (on dry weight basis) of substrate material. The moisture level of substrates was maintained around $65-70 \%$ throughout the study period by periodic sprinkling of adequate quantity of tap water. Containers were placed in a humid and dark room at a temperature of $28.2 \pm 0.25{ }^{\circ} \mathrm{C}$ (mean \pm SEm of temperature recorded during the experimental duration). The growth and cocoon production by earthworm was measured in each experimental container. Earthworms and cocoon, which were produced during the experiment, were separated from the substrate material by hand sorting after which worms were washed in tap water to remove the adhering material from their bodies and subsequently weighed on live weight basis. Then all measured earthworms were returned to the concerned container. Separated cocoon were counted and introduced in separate bedding containing the same material in which their parents were reared. On the basis of the obtained data about the biomass and cocoon numbers, other parameters of earthworm such as biomass increase rate (mg/day), maximum weight achieved and reproduction rate (cocoon/ worm/ day) were produced with the help of the recorded data for different treatments. The homogenized sub-samples of the substrate material (10 g dry weight basis) were collected the days $0,30,60,90,120$ and 150 from each experimental container and they were analyzed for organic C (Walkley and Black, 1934), total Kjeldahl nitrogen (TKN) (Jackson, 1973), available P (Anderson and Ingram, 1993) and exchangeable K (Simard, 1993). The C: $\mathrm{N}$ ratio was calculated from the measured values of $\mathrm{C}$ and $\mathrm{N}$. Paired sample $t$-tests were 
performed to identify the significant difference between experimental beddings for both species in respect to the chemical parameters of the end product (vermicompost) and earthworm growth parameters (earthworm weight gain, individual growth rate, total cocoons numbers, reproduction rate, total mortality, etc.).

\section{RESULTS AND DISCUSSION}

Table 1 shows the values of ready vermicompost prepared from domestic waste. Data clearly indicated that inoculation of earthworm in domestic waste caused significant changes in the chemical composition of waste. The $\mathrm{pH}$ values were lower in vermicompost than the initial material and a reduction was recorded between the ranges of 11.3 and $13.2 \%$. Organic C showed a significant $(P<0.05)$ loss, i.e. $36.8 \%(P$. excavatus) and $37.2 \%$ (P. sansibaricus) in vermibeds by the end of the experiment (Table 1), but the difference in both species for organic $C$ content reduction was not statistically significant ( $t$-test: $P=0.764)$. Total k je da n । n itrog en content increased between 85.0 (P. excavatus) and $95.6 \%$ (P. sansibaricus) in the studied substrates by the end of the experiment (Table 1 ). As compared with the control beddings, the earthworm showed 1.6-1.7 fold increment in the total $\mathrm{N}$ content. However, $P$. sansibaricus showed $\sim 6 \%$ more TKN in vermicomposted material than the material processed by $P$. excavatus ( $t$-test; $P=0.002$ ). The available $\mathrm{P}$ was also higher in the end product (vermicompost) as compared to the initial feed mixture. The vermicompost, prepared by $P$. excavatus and $P$. sansibaricus, respectively showed 103.0 and $110.3 \%$ more $P$ content than the initial material (Table
1). Comparatively, $P$. sansibaricus showed $\sim 6 \%$ more concentration of the available $P$ than $P$. excavatus in the end product (vermicompost), but the difference was not found statistically significant ( $t$-test; $P=$ 0.269) (Table 1). Exchangeable K was also higher in the vermicomposted material by the end of the experiment. The highest increase in the potassium content was in the vermibeds processed by $P$. excavatus (89\% higher than initial concentration), which is slightly higher ( $t$-test: $P=0.004)$ than those by $P$. sansibaricus ( $86.1 \%$ more than initial). The C:N ratio indicates the compost maturity as well as quality.

In this study, the $\mathrm{C}: \mathrm{N}$ ratio of the vermicomposted material was lower than the initial feed mixture and the highest reduction was in vermicompost processed by $P$. sansibaricus (67.7\%). The difference in the $\mathrm{C}: \mathrm{N}$ ratio significantly varied between the treatments $(P=0.002)$. The growth and reproduction performance of composting earthworms was also evaluated during the experimentation. As summarized in Table 2, earthworm showed a considerable increase in individual live weight. The maximum individual live weight differed significantly $(t$-test: $P<0.01)$ between the studied species. $P$. excavatus and $P$. sansibaricus reached their maximum individual live weights after 90 days (560.33 $\pm 16.44 \mathrm{mg})$ and 120 days (526.0 $\pm 11.27 \mathrm{mg})$, respectively. The maximum weight gain was followed by weight loss by the end of the experiment (Fig. 1). At the end of the experiment, the mean individual weight of $P$. excavatus and $P$. sansibaricus was recorded: $509.67 \pm 12.01$ and $481.67 \pm 22.75$, respectively ( $t$-test; $P<0.01)$.

Table 1: Chemical characteristics $(\mathrm{g} / \mathrm{kg})$ of vermibeds at the start and at the end (mean $\pm \mathrm{SD}, \mathrm{n}=3$ )

\begin{tabular}{|c|c|c|c|c|c|}
\hline \multirow{3}{*}{ Parameter } & \multirow{3}{*}{ At start (0 day) } & \multicolumn{3}{|c|}{ At end (after 150 days) } & \multirow[t]{3}{*}{$t$-test } \\
\hline & & \multirow[t]{2}{*}{ Composting } & \multicolumn{2}{|c|}{ Vermicomposting } & \\
\hline & & & P. sansibaricus & P. excavatus & \\
\hline $\mathrm{pH}$ & $8.56 \pm 0.06$ & $8.21 \pm 0.02$ & $7.43 \pm 0.02$ & $7.59 \pm 0.03$ & $\mathrm{P}=0.003$ \\
\hline Organic C (g/kg) & $318.8 \pm 0.05$ & $179.1 \pm 0.10$ & $200.2 \pm 0.19$ & $201.6 \pm 0.11$ & $P=0.870$ \\
\hline Total N (g/kg) & $10.4 \pm 0.05$ & $11.8 \pm 0.06$ & $20.36 \pm 0.10$ & $19.26 \pm 0.06$ & $P=0.002$ \\
\hline Available P (g/kg) & $3.02 \pm 0.04$ & $4.78 \pm 0.08$ & $6.35 \pm 0.06$ & $6.13 \pm 0.06$ & $P=0.269$ \\
\hline Exchangeable K (g/kg) & $5.19 \pm 0.07$ & $7.86 \pm 0.05$ & $9.60 \pm 0.67$ & $9.55 \pm 0.66$ & $P=0.004$ \\
\hline $\mathrm{C}: \mathrm{N}$ ratio & $30.6 \pm 0.15$ & $15.2 \pm 0.08$ & $9.89 \pm 0.05$ & $10.40 \pm 0.04$ & $\mathrm{P}=0.002$ \\
\hline Organic matter (g/kg) & $552.3 \pm 0.05$ & $310.2 \pm 0.18$ & $348.1 \pm 0.32$ & $349.2 \pm 0.20$ & $P=0.673$ \\
\hline $\mathrm{C}: \mathrm{P}$ ratio & $102.8 \pm 0.89$ & $37.5 \pm 0.59$ & $31.7 \pm 0.28$ & $32.7 \pm 0.35$ & $\mathrm{P}=0.102$ \\
\hline
\end{tabular}


Vermicomposting of domestic waste by using two epigeic earthworms...

Table: 2 Biological productivity of earthworms in waste decomposing system (mean \pm SD, $n=3$ )

\begin{tabular}{|c|c|c|c|}
\hline Parameter & P. sansibaricus & P. excavatus & $t$-test \\
\hline \multicolumn{4}{|l|}{ Mean individual biomass } \\
\hline At start & $252.33 \pm 3.21$ & $254.0 \pm 5.29$ & $P=0.764$ \\
\hline At end & $481.67 \pm 22.75$ & $509.67 \pm 12.01$ & $P=0.010$ \\
\hline Maximum individual weight achieved (mg) & $526.0 \pm 11.27$ & $560.33 \pm 16.44$ & $P=0.011$ \\
\hline Maximum individual weight gained & After 90 days & After 120 days & - \\
\hline Net individual weight gained (mg) & $273.67 \pm 13.43$ & $306.33 \pm 12.74$ & $P=0.009$ \\
\hline Growth rate (mg wt./worm/day) & $2.28 \pm 0.11$ & $3.40 \pm 0.15$ & $P=0.111$ \\
\hline Total cocoon nos. after 150 days & $169.67 \pm 17.10$ & $385.67 \pm 8.02$ & $P=0.009$ \\
\hline Cocoon production rate (cocoon/worm) & $8.98 \pm 1.32$ & $19.98 \pm 0.91$ & $P=0.008$ \\
\hline Cocoon production rate (cocoon/worm/day) & $0.06 \pm 0.007$ & $0.13 \pm 0.005$ & $P=0.008$ \\
\hline Total mortality after 150 days & $5.0 \pm 5.0$ & $3.33 \pm 5.78$ & $P=0.423$ \\
\hline
\end{tabular}

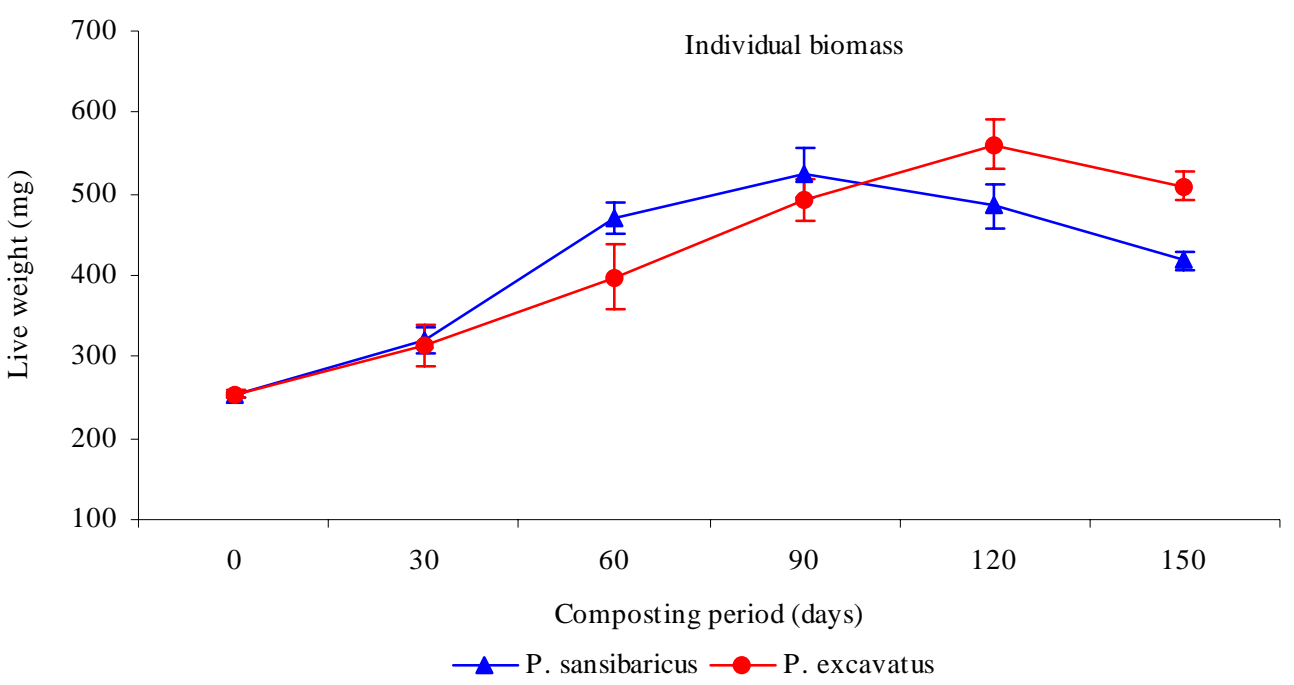

Fig. 1: The growth and cocoon production rate

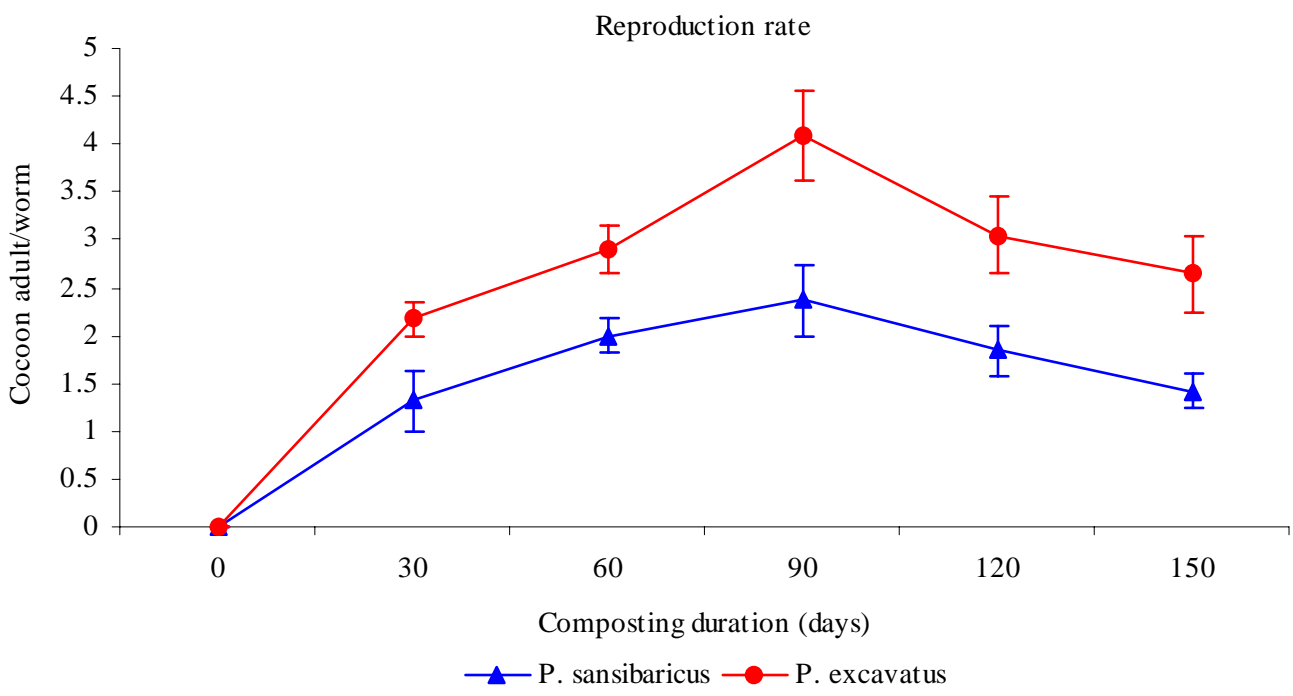

Fig. 2: The growth of $P$. excavatus and $P$. sansibaricus during vermicomposting process 
As data indicate, $P$. sansibaricus showed $\sim 12 \%$ more weight gain than $P$. excavatus $(t=10.36, P$ $<0.001)$. Comparatively, $P$. excavatus showed more individual growth rate (mg/worm/day) $3.40 \pm 0.15$ in household waste, but it was not found statistically different from those by $P$. sansibaricus $(2.28 \pm 0.11)$ $(t=2.75, P>0.05)$ (Table 2$)$. The cocoon production between $P$. excavatus and $P$. sansibaricus also varied statistically ( $t$-test: $P<0.05) . P$. excavatus showed more cocoon numbers (358.67 \pm 8.02 ), about $111 \%$ more than those by $P$. sansibaricus (Table 2 ). The reproduction rate (cocoon/worm/day) was also found at its maximum in $P$. excavatus $(0.13 \pm 0.005)$ and it was significantly more than that by $P$. sansibaricus $(0.06 \pm 0.007)$ (t-test: $P>0.05)$. The cocoon rate (cocoon/worm) was much better in $P$. excavatus than $P$. sansibaricus (Table 2). However, the peak of cocoon rate followed by a drastic decline in both species after 90 days of experimentation (Fig. 2). During composting $P$. sansibaricus showed the maximum mortality rate. However, the observed difference in both species of worm for mortality was not found significant ( $t$-test: $P<0.05)$.

The vermicomposting process refers to earthworms feeding on organic matter and microbial degradation. In a vermicomposting process, inoculated earthworms maintain aerobic condition in the wastes, convert a portion of the organic material into worm biomass and respiration products and expel the remaining partially stabilized product (vermicompost). In this study, a reduction in the $\mathrm{pH}$ of waste was recorded in the end. The variability in $\mathrm{pH}$ could be due to the production of $\mathrm{CO}_{2}$ and organic acids during organic wastes decomposition. Haimi and Huhta, (1986) during their study on the vermicomposting of some organic residues concluded that the lower $\mathrm{pH}$ in the end product (vermicompost) might have been due to the production of $\mathrm{CO}_{2}$ and organic acids by microbial decomposition during the process of bioconversion of different substrates in the beds. According to Ndegwa, et al., (2000), the shifting of $\mathrm{pH}$ to lower levels could be attributed to mineralization of nitrogen and orthophosphates and bioconversion of organic materials into intermediate species of the organic acids. However, the difference between the $\mathrm{pH}$ values of the vermicompost, prepared by $P$. excavatus and $P$. sansibaricus, could be related to the species-specific difference in their mineralization efficiency although it requires more elaborative study for confirmation.
In general, an organic $C$ loss has been observed during the vermicomposting process (Kale, et al., 1982; Garg and Kaushik, 2005; Suthar, 2007a). Earthworm modifies substrate conditions, which consequently affects carbon losses from the substrates through microbial respiration in the form of $\mathrm{CO}_{2}$ and even through mineralization of organic matter. Elvira, et al., (1998) stated that a large fraction of organic matter in the initial substrates was lost as $\mathrm{CO}_{2}$ (between 20 and $43 \%$ as total organic carbon) by the end of the vermicomposting period. The vermicomposted material had a greater nitrogen content. The inoculation of worms in waste material considerably enhances the amount of $\mathrm{N}$ due to earthworm mediated nitrogen mineralization of wastes. It also suggested that the earthworm also enhances the nitrogen levels of the substrate by adding their excretory products, mucus, body fluid, enzymes and even through the decaying tissues of dead worms in vermicomposting sub-system (Suthar, 2007a). The vermicompost prepared by both earthworm species showed a considerable difference for total $\mathrm{N}$ content. The observed difference could be attributed directly to the feeding preferences of individual earthworm species and indirectly to mutualistic relationship between ingested microorganisms and intestinal mucus which might be species-specific. The enhanced $\mathrm{P}$ level in ready vermicompost suggests phosphorous mineralization during vermicomposting process. Lee, (1992) suggests that the passage of organic matter through the gut of earthworm's results in phosphorus is converted to forms, which are more available to plants. The release of phosphorous in the available form is performed partly by earthworm gut phosphatases and further release of $\mathrm{P}$ might be attributed to the P-solubilizing microorganisms present in worm casts. Le Bayon and Binet, (2006) concluded that the impact produced by earthworm on $\mathrm{P}$ biogeochemical transformations in the soil depends on the close relationship between the properties of the organic $P$ source and the specific burrowing behaviour and food preferences of worms. Some previous studies also indicate enhanced potassium content in vermicompost by the end of the experiment (Manna, et al., 2003; Suthar, 2007a). The results obtained in this study are similar to those by Delgado, et al., (1995), who demonstrated higher potassium concentration in the end product prepared from sewage sludge. The C:N ratio of the substrate 
material reflects the organic waste mineralization and stabilization during the process of composting or vermicomposting. The lowest $\mathrm{C}: \mathrm{N}$ ratio in $P$. sansibaricus processed material indicates that this species enhances the organic matter mineralization more efficiently than $P$. excavatus. The loss of carbon as carbon dioxide through microbial respiration and simultaneous addition of nitrogen by worms in the form of mucus and nitrogenous excretory material lowered the C:N ratio of the substrate (Suthar, 2007a). Inoculated worms showed a significant growth rate and reproduction activities when introduced into wastes for long durations. Earthworm attained the peak of their individual after a certain duration which followed a decline by the end of the experiment. Neuhauser, et al., (1988) have reported a similar trend in weight loss in E. fetida for a longer exposure duration in treated sludge. This was correlated with the conversion of most of the used substrate to vermicompost, which cannot further support their growth. A similar trend of weight loss has been also reported by Suthar, (2007b) for P. excavatus, while using a variety of waste materials. The maximum growth rates of each one was calculated by taking the maximum weight gain achieved by earthworm, subtracting the initial mean individual weight and dividing the weight increase by the number of days needed to reach the maximum weight (Edwards, et al., 1998). Edwards, et al., (1998) studied the growth patterns of $P$. excavatus on the separated cattle solids and reported the range of growth rate between 0.6 (mg/worm/day) and 7.6 (mg/worm/day/) (25-30 ${ }^{\circ} \mathrm{C}$ ). Recently, Suthar, (2007b) reported a maximum growth rate (mg/worm/day) by $P$. excavatus between the range of $3.69 \pm 0.08-2.35 \pm 0.16$ on different feed mixtures (crop residue mixed with cattle solids, farm yard manure and municipal solid waste etc). The difference between the present and past studies (Kale, et al., 1982; Reinecke, et al., 1992; Edwards, et al., 1998; Suthar, 2007a and b) on the maximum weight increase and growth rate in composting earthworm could be due to the difference in substrate quality or due to fluctuating environmental conditions. Moreover, it is also concluded that the observed difference between $P$. sansibaricus and $P$. excavatus for growth rate was due to the species-specific growth patterns or could be related to the feed preferences by individual earthworm species. Recently, Suthar, (2007a and c) demonstrated the growth and reproduction performance of $P$. sansibaricus on a variety of organic wastes. He reported the cocoon rate (cocoon/worm) between the ranges of $2.16 \pm 0.18$ and $3.99 \pm 0.25$. However, the cocoon rate by $P$. sansibaricus in this study is much better (Table 2) than the previous report (Suthar, 2006). Similarly, in the previous reports, the cocoon reproduction rate for $P$. excavatus has been described differently, e.g. 0.15 cocoons/worm/day at $25^{\circ} \mathrm{C}$ on cattle solids (Kale, et al., 1982), 0.33 cocoons/ worm/day at $25^{\circ} \mathrm{C}$ and 0.12 cocoons/worm/day at 25$37^{\circ} \mathrm{C}$ on cattle solids (Reinecke, et al., 1992), 0.82 and 0.29 cocoons/worm/day respectively at 25 and $30^{\circ} \mathrm{C}$ on cattle solids (Edwards, et al., 1998) and between 0.15 (in farmyard manure) and 0.23 (in mixed crop residue mixed with cow dung in $1: 1$ ratio) at $29.4{ }^{\circ} \mathrm{C}$ (Suthar, 2007b).

In most of the previous studies, cattle dung and plant-derived waste were used as a substrate, whereas in the present study, a different type of organic waste has been used. Therefore, the differences in the present and past results could be related to the nature of the feed material or to any environmental variable. Suthar, (2007a) demonstrated that $P$. sansibaricus showed a better weight gain as well as reproduction performance beddings that contained more nitrogen contents. Therefore, the difference might be due to substrate chemistry or due to species-specific feeding behaviour or both. Earthworm mortality appears as a major problem during the vermicomposting of such types of organic wastes. However, the degradation probably caused drastic changes in some environmental characteristics of decomposing vermibeds. The changed condition influences the survival rate of the worms.

The difference in worm mortality between the studied species could be related to the speciesspecific composting behaviour or to specific tolerance nature of earthworm for changing microenvironment in composting sub-system. This paper provides information on the comparative biology and composting efficiency of two commonly distributed tropical earthworm, i.e. P. excavatus and $P$. sansibaricus. All in all, P. excavatus appeared as more efficient than $P$. sansibaricus in terms of organic waste mineralization. The growth and reproduction performance was also noted better in P. excavatus. The observed difference between $P$. sansibaricus and $P$. excavatus for their growths, reproduction efficiencies and composting potentials could be a 
species-specific character, or it could be related to the quality of the substrate used for their culture. This study clearly indicates that vermicomposting of domestic waste could be an effective technology to convert the negligible resource into some value-added products, e.g. vermicomposts and earthworms on a low-input basis.

\section{REFERENCES}

Anderson, J. M.; Ingram, J. S. I., (1993). Soil organic matter and organic carbon. In: Anderson, J. M. Ingram, J. S. I. (Eds), Tropical soil biology and fertility: A hand book of mwthods, Wallingford, UK, CAB Internationals.

Benitez, E.; Nogales, R.; Elvira, C.; Masciandaro, G.; Ceccanti, B., (1999). Enzyme activities as indicators of the stabilization of sewage sludges composting with Eisenia foetida. Bioresource Tech., 67, 297-303.

Butt, K. R., (1993). Utilization of solid paper mill sludge and spent brewery yeast as a food for soil-dwelling earthworms. Bioresource Tech., 44, 105-107.

Delgado, M.; Bigeriego, M.; Walter, I.; Calbo, R., (1995). Use of California red worm in sewage sludge transformation. Turrialba, 45, 33-41.

Dominguez, J.; Edwards, C. A.; Ashby, J., (2001). The biology and population dynamics of Eudrilus eugeniae (Kinberg) (Oligochaeta) in cattle waste solids. Pedobiologia., 45, 341353.

Edwards, C. A.; Dominguez, J.; Neuhauser, E. F., (1998). Growth and reproduction of Perionyx excavatus (Perr.) (Megascolecidae) as factors in organic waste management. Biol. Fert. Soils, 27, 155-161.

Elvira, C.; Sampedro, L.; Benitez, E.; Nogales, R., (1998). Vermicomposting of sludges from paper mill and dairy industries with Eisenia andrei: A pilot scale study. Bioresource Tech., 63, 205-211

Garg, P.; Gupta, A.; Satya, S., (2006). Vermicomposting of different types of waste using Eisenia foetida: A comparative study. Bioresource Tech., 97, 391-395.

Garg, V. K.; Kaushik, P., (2005). Vermistabilization of textile mill sludge spiked with poultry droppings by epigeic earthworm Eisenia fetida. Bioresource Tech., 96, 10631071.

Haimi, J.; Huhta, V., (1986). Capacity of various organic residues to support adequate earthworm biomass for vermicomposting. Biol. Fert. Soils, 2, 23-27.

Jackson, M. L., (1973). Soil chemical analysis. Pranctice Hall of India, New Delhi.
Kale, R. D.; Bano, K.; Krishnamoorthy, R. V., (1982). Potential of Perionyx excavatus for utilizing organic wastes. Pedobiologia, 23, 419-425.

Le Bayon, R. C.; Binet, F., (2006). Earthworm changes the distribution and availability of phosphorous in organic substrates. Soil Biol. Biochem., 38, 235-246.

Lee, K. E., (1992). Some trends opportunities in earthworm research or: Darwin's children. The future of our discipline. Soil Biol. Biochem., 24, 1765-1771.

Manna, M. C.; Jha, S.; Ghosh, P. K.; Acharya, C. L., (2003). Comparative efficiency of three epigeic earthworms under different deciduous forest litters decomposition. Bioresource Tech., 88 (3), 197-206.

Ndegwa, P. M.; Thompson, S. A.; Das, K. C., (2000). Effects of stocking density and feeding rate on vermicomposting of biosolids. Bioresource Tech., 71, 5-12.

Neuhauser, E. F.; Loehr, R. C.; Makecki, M. R., (1988). The potential of earthworms for managing sewage sludge. In: Edwards, C. A., Neuhauser, E. F. (Eds), Earthworm in waste and environmental management. SPB Academic Publishing, The Hugue, 9-20.

Reinecke, A. J.; Viljoen, S. A.; Saayman, R. J., (1992). The suitability of Eudrilus eugeniae, Perionyx excavatus and Eisenia fetida (Oligochaeta) for vermicomposting in southern Africa in terms of their temperature requirements. Soil Biol. Biochem., 24 (12), 1295-1307.

Simard, R. R., (1993). Ammonium acetate extractable elements. In: Martin, R., Carter, S., (Eds), Soil sampling and methods of analysis. Lewis Publisher, Florida, USA. 39-43.

Suthar, S., (2006). Potential utilization of guargum industrial waste in vermicompost production. Bioresource Tech., 97, 2474-2477.

Suthar, S., (2007a). Vermicomposting potential of Perionyx sansibaricus (Perrier) in different waste materials. Bioresource Tech., 98, 1231-1237.

Suthar, S., (2007b). Nutrient changes and biodynamics of epigeic earthworm Perionyx excavatus (Perrier) during recycling of some agriculture wastes. Bioresource Tech., 98, 1608-1614.

Suthar, S., (2007c). Production of vermifertilizer from guar gum industrial waste by using composting earthworm Perionyx sansibaricus (Perrier). Environmentalist, 27, (1), 329-335.

Walkley, A.; Black, I. A., (1934). An examination of the Degtjareff method for determining soil organic matter and prepared modification of the chronic acid titration method. Soil Sci., 34, 29-38. 


\section{AUTHOR (S) BIOSKETCHES}

Suthar, S., M.Sc., Ph.D., Lecturer in Post Graduate Department of Zoology, S.G.N. Khalsa (PG) College, Sri Ganganagar-335 001, India. His major research areas are vermitechnology, ecotoxicology and solid waste management. Email:sutharss_soilbiology@yahoo.co.in

Singh, S., M.Sc., Ph.D., Lecturer in Department of Chemistry, N.M. (PG) College, Hanumangarh Town-335 513, India. Her major areas of research are environmental chemistry, waste recycling, medicinal plant chemistry. Email:sushmas_chem@yahoo.co.in

This article should be referenced as follows:

Suthar, S.; Singh, S., (2008). Vermicomposting of domestic waste by using two epigeic earthworms (Perionyx excavatus and Perionyx sansibaricus). Int. J. Environ. Sci. Tech., 5(1), 99-106. 